\title{
MISSIONARY PRINCIPLES OF THE EARLY CHURCH
}

AlL who are in touch with missionary problems to-day are agreed that the situation is a very acute one. The wide spread of missions during the past hundred years has vastly enlarged the superficial area of the Christian Church, and at the same time raised complex problems, theological and ecclesiastical, which were quite unknown to the divines of the seventeenth and eighteenth centuries. This paper is an attempt to suggest some lines along which a solution of some of these problems may be found, by reference to the practice of the early Church.

The modern missionary movement had its origin in the evangelical impulse to save individual souls. But the success of that work in winning so many thousands of individuals to personal faith in Jesus Christ has opened up to the eye of the Christian statesman new vistas of possible advance. Exactly how the change has come about it is hard to say, but it is certain that to-day we think in terms of nations, not individuals : and our missions are directed not exclusively to the conversion of as many souls as possible but far more to the planting in every race of a living branch of the Church, capable of adapting itself to its surroundings, and of enriching itself by absorbing those aspects of truth which are already grasped by each race previous to conversion.

This shifting of the point of view from the salvation of the individual to that of the race seems to underlie that great family of problems which is concerned with the relation between the home Church and the Church in the mission field. When the sole object of the missionary was 
to persuade as many heathen as possible of the truth of the Gospel it mattered little whether the convert became europeanized or not. Indeed the tendency was to regard even the innocent accessories of life in a heathen nation as necessarily inconsistent with Christianity. But when once the emphasis is seen to rest primarily on the salvation of the nation, it becomes a matter of the first importance whether the Christian Chinese or Indian becomes a poor copy of a European model, or whether he retains his national habits of thought and life, transformed, enlarged and ennobled by faith in Christ and by his membership in the Church, which is the body of Christ. It is being realized more and more clearly that an indigenous Christianity of the East cannot be in all respects identical with the Christianity which is now indigenous in the West. In essence it must be the same, for there is but one Lord, one faith, one baptism : but in matters of less importance it may differ.

Hence the greatest theoretic problem before the Church in the world to-day is, in widest terms, that of the relation of the content of the faith to its form. We are all convinced that some parts of current western Christianity are merely the results of the history of religion in Europe, and without universal validity : e.g. the state establishment of religion. Correspondingly, we are all convinced that there is an essence of Christianity without which no true branch of the Church can exist. The difficulty arises when we begin to attempt to distinguish between the essential and the non-essential, the content and the form. Of necessity any attempted distinction involves many of the controversial questions which have been debated in Europe for four hundred years : and at the first glance it might seem as though questions of this sort were best passed over in silence, in the interests of peace and mutual tolerance. But that policy is not really in the interests of either truth or safety. An assumption which remains in the background of our thoughts is not less influential in practice than one which finds clear expression in language. 
The problem which we are to consider may be stated thus: What elements, theological or ecclesiastical, in current western Christianity, as evolved during 1900 years, are we to regard as essential, and therefore necessary for the growing Church of the East?

In attempting to answer this question, the first point which needs emphasis is that this problem is at least as old as St. Paul. For the missionary situation in his time resembled in a remarkable degree that of to-day, both as regards the missionary and his audience. It is indeed true that the Christian faith was then a new doctrine, but the place of a past history of its own was taken by the past history of Judaism. The earliest Christians remained Jews by religion as well as by race. The holders of this new doctrine, based on the old Jewish theology and Jewish Church, had to face a world vastly outnumbering them, a world with which they were brought into the closest possible contact. To St. Paul and his contemporaries the inhabitants of China or America meant no more than the problematical inhabitants of Mars mean to us. The world for them meant the Graeco-Roman world, i.e. the races permeated by Greek civilization, and under the direct or indirect suzerainty of Rome. Within this little world there was a degree of unification and a free interchange of thought, such as has never been paralleled until last century. The dominant materialism of the Roman mind was in ceaseless conflict with the mystical philosophy of the East. The Roman religion of politics and common sense, of the augurs and flamens who made religion the tool of the dominant party in the State, had been replaced in popular devotion by the mystery religions of eastern origin, and in state recognition by the worship of Rome and Augustus, which occupied in the Empire just the same position as was until the recent revolution held in China by the veneration of Confucius. It is to no small extent true to say that national boundaries of thought and life had no more place in the Empire than had political frontiers. The 
whole weltering mass was a vast confusion of heterogeneous elements, held together in a semblance of outward unity by the political supremacy of Rome. The principle of intellectual unity, if any such could be found, was that of Hellenism, which had always displayed a certain affinity for oriental forms of thought, yet was essentially western in its development and capable of providing an intellectual basis for western materialism.

It was this world which St. Paul, himself not unacquainted with current Hellenism, set out to conquer for Christ, by preaching Christ in a language of thought and word which that world could understand and assimilate. Accordingly he appeased their intellectual hunger by such a statement of the Christian truth as seemed to him, under the guidance of the Holy Spirit, to meet their case. But on his return to Jerusalem, then the headquarters of the Church, his action was called in question, his statement of the essentials of the faith was disputed, and he found himself in the midst of the Judaistic controversy. The issue of that controversy made it for ever plain that Christianity was not to be cramped by the rigid forms of Judaism. St. Paul died as he had lived a devout and orthodox Jew; but he had proved that the essence of the Christian faith was clearly to be distinguished from the Jewish forms in which it had at first been presented.

The battle thus begun has not ended even yet in Europe, but the period of intensest conflict was that of the first three or four centuries after Christ. Hence it is to these centuries especially that Christian statesmen ought to turn, in order to find fruitful analogies for their guidance in solving the missionary problems of to-day. For church history has a unity which is lacking in secular history : since it is in principle the history of the expression of the one faith under the conditions of varying ages. Hence it is certain that for satisfactory principles of missionary statesmanship the whole history of the Church must be carefully reviewed. It is useless to stop at the Reformation in our backward 
survey : for the Reformation marks merely the victory of western, and especially Teutonic ideals over the old Graeco-Roman habits of thought as embodied in the mediaeval Church, not the final statement of Christianity in forms of thought capable of universal acceptance.

If we carry our study of church history back to the beginning, we shall find that modern civilization is in many respects a truthful counterpart of Graeco-Roman civilization. In both there is a strong and dominating tendency towards materialism. For if Rome taught the nations nothing else, she certainly taught them to lust after power, wealth and luxury. In point of actual achievement, material civilization never reached so high a pitch after the early Empire until the nineteenth century.

Coupled with this all-pervading materialism was, and is, an equally wide-spread scepticism. The special tone or colour of scepticism to-day is what we call scientific, i.e. a method of exact analysis and accurate definition which aims at interpreting the vaguer realms of thought and belief by methods learned in the more concrete study of physical nature. The scepticism of the Roman Empire was more metaphysical; yet we must remember that both the Stoics and the Epicureans based their philosophy largely on cosmology, i.e. a philosophic theory of the origin of the world, their theories corresponding pretty closely in principle, if not in detail, with the metaphysical bases of modern science as expounded by such thinkers as Spencer or Haeckel. But the chief similarity between the scepticism of the Empire and that of to-day lies in its thoroughly radical charactcr. We see this strikingly when we compare Plato and Aristotle on the one hand, and Kant and Spencer on the other, with Thomas Aquinas. To the scholastics there were many assumptions which it were impious to analyse. But to Plotinus and Hegel, Seneca and Moliêre, Juvenal and Bernard Shaw, there are no assumptions, speculative or ethical, that cannot be analysed and, if need be, abandoned.

A third aspect in which the situation in the first few 
centuries resembles that of the present is the fact that the early Church was in the closest contact with the East. It was no accident that the Nestorian Church spread half across Asia, and as far east as China. Its spread merely proved that the Church was in vital contact with the eastern peoples. But with the decay of the Byzantine Empire the intimacy of that contant was destroyed. In the middle ages the only medium of communication was the bastard religion of Islam. It was only in the last century that the extension of the British Empire in India, and the close commercial and political relations set up between European Powers and China and Japan, brought the West directly face to face with the East again.

When this series of facts is borne in mind, it can hardly be disputed that great light should he thrown upon modern missionary problems by the literature of the first three Christian centuries. Yet it must be admitted that most missionary theorists show not even the slightest acquaintance with this source of guidance. There is indeed constant appeal to the New Testament, and that appeal is now vastly more intelligent and less formal than it used to be, for we are ready to set the words of the apostles and of Christ Himself in their historical setting. But we must not forget that the New Testament record closes with the Church not so securely planted in Asia Minor or Europe as it is today in India or Japan. Setting aside the personal factor, i.e. the presence of the apostles and others who had been eyewitnesses of the Christian facts, we must admit that the Church of the first century was not only smaller in numbers but also less influential than the Church in India to-day. When Pliny wrote his famous letter to Trajan about the Christians, at most ten years after the last book of the New Testament, he wrote in order to explain their customs to that most methodical of emperors, whose attention to detail descended to the discussion of the local fire-brigade at Nicomedia. Indeed Trajan seems to have been ignorant, if not that there were people called Christians, at any rate 
of their customs : a statement which certainly could not have been made about the Chinese emperor twenty years ago. Hence it seems clear that in order to obtain precedents for our solution of modern missionary problems, we must not confine ourselves to the New Testament, but must study also the writings of the Greek and Latin Fathers. This fact seems so obvious that I should not have thought it needful to dwell upon it but that it seems hardly to have occurred to any missionary writer of the present day, at least in England. The only references to patristic literature and its value for modern missions which the present writer has ever come across are in the lives of Bishop French of Lahore and Bishop Bickersteth of South Tokyo.

The field of patristic literature is so vast that any survey of its contribution to missionary theory must necessarily be of a most superficial kind. However it may be worth while to attempt to sketch in broadest outline the principles which seem to underlie that literature in its dealings with current heathenism, remembering that the selection of the apparently most important principles must be to no small extent determined by each reader's previous sentiments.

In the first place, then, we must consider the attitude of the ancient Fathers to materialism.

No modern writer could feel more acutely than did they the pressure of the material civilization in which they lived. That materialism was certainly cruder and more gross outwardly than that of to-day : yet in principle it was the same. The attack on this materialism, as we read it in the Fathers, follows two main lines. First, they asserted the spirituality of life by their strong insistence on the resurrection and the future life. A doctrine of future rewards and punishments can be stated in a form so crude as to terrify the most besotted sensualist into a trembling attention : the early Fathers had no hesitation in painting pictures of hell and of heaven in order to deter from vice or attract to virtue. Moreover, their doctrine of a future life was two-cdged; for, while its spirituality demolished the 
materialism of the western, its clear presentation of the doctrine of the resurrection and resolute insistence on the permanence of personality were directed against the oriental conceptions of reincarnation on the one hand, and absorption in God on the other. Secondly, they combated practical materialism by teaching practical Christian morality, which is always the best answer to the petulance of a demoralized society. To an age that was rotten to the core with social impurity, the Christian Church presented an example of the most serene purity of life: to an age of oppression and self-seeking, a model of humility and charity.

The other great problem which they set themselves to solve was that of philosophy.

To a modern student, accustomed to the methods of western literature, the Greek Fathers seem highly philosophical in their treatment of Christianity : but they regarded themselves as in antagonism to current philosophic thought in no small degree. The western form of that philosophy which they condemned was either a radical scepticism, as incompatible with faith as a radical pessimism is with morality, or else a narrowly intellectual construction, such as Stoicism. Eastern philosophy was more akin to mysticism, a mysticism which had as its ideal the absorption of the individual in God. Hence, while with one hand the Church fought for the spirituality of life, with the other she contended for the truth of personality and the real existence of material nature, which we experience as an associate element in that personality. Gnosticism was as dangerous an enemy as scepticism : for an excess of credulity is as destructive of true religion as a defect of belief. The patristic defence to both these forms of philosophic attack centred in a strong presentation of the historical life of Christ, as recorded in the Bible and witnessed to by the living Church. This line of defence must of necessity be the strongest, since it rests our human attempts to justify the wisdom of God upon the act of God Himself : for $\mathrm{He}$ could find no better way to convince mankind of His 
existence and His love than the incarnation of Christ. The eternal nature and being of God was attested to the minds of men by the historic fact of the incarnation.

But it is to be noted that both these lines of defence, against materialism and against heathen philosophy, were intended rather to ward off enemies than to supply constructive teaching for believers. The practical building up of Christians in the faith, and their qualification to defend themselves, was effected in three ways.

The first and most important means was the organized life of the Church. The Church as an organization fought and defeated the Empire. The life of the individual Christian was preserved and educated in the faith by his close association with his fellow-believers. This organization was, in theory and in practice, indissolubly bound up with the two necessary factors of Christian unity, the sacraments and the ministry. As in the New Testament, so in the early Fathers, we learn more from what is hinted at or casually mentioned on these matters than from direct references. But the constant appeals to current belief with regard to Baptism and the Eucharist make it plain that these were the two most important bonds by which Christians were drawn together. And the same is true of the ministry. Whatever view we may hold as to the actual origin and precise status of the ordained ministry, it is quite clear that the existence of the ministry was one of the main factors in the unification of the Church and its strengthening to resist all external pressure.

A second great means we may discern in the gradual expansion of belief in the Bible and its increasing use as a principal factor in personal edification. The Bible of the earliest Church was of course the Old Testament : but the attitude of the early Christian teachers and apologists to the old Testament requires some explanation. For it was the Bible of the Jews also, and Judaism was in some sense in competition with the Church. The Jews enjoyed special privileges within the Empire, and exercised no incon- 
siderable influence, largely due to their financial abilities. The Church had originated among the Jews, and for a considerable period the heathen population regarded a Christian as a peculiar sort of Jew. It was under the special liberty of worship allowed to the Jews that the Church first took root, for the Jews were not forced to join in the worship of Rome and Augustus. It was their growing hostility which first forced the Church into open opposition to the Government. The Jews were in fact the Church's bitterest enemies. Hence a great problem of internal policy was that of making clear the distinction of Christianity and Judaism without abandoning all that providential preparation for the coming of Christ which was clearly seen in the history of Israel. The Church had to show proof that the religion of Christ was an advance upon that of Moses and the prophets. Sacred books were then, as now, familiar to the East, and so the Old Testament became the pivot of controversy. The Church sought to establish the truth of Christianity by displaying the whole of the Old Testament in a Messianic light. Not only were the passages familiar to us so regarded : there was scarcely a verse which might not be tortured into a prophecy by a method of allegorical interpretation which often lost sight entirely of the original meaning which the writer had intended to convey. This method of interpretation was unjustifiable from the modern point of view, yet by it the Church learned to put the Old Testament in the forefront of its life, and from its experience of the value of such use of it began to rank some few of the known writings of apostles alongside of it as sacred scriptures. This was God's way of teaching those early believers the truth of biblical inspiration. It may seem strange to us, yet we must remember that it has been only under pressure of controversy that we have been learning in recent years to take up an historical attitude to the Bible, and thus to understand more adequately some of the meanings which God wills to convey to us through the writings of His saints. The result for the early Church was that each member had 
access to a volume of sacred writings which alone could preserve in its purity the record of our Lord's life and teaching, together with the inspired commentaries upon it contained in the epistles.

A third means of edification was the definite formulation of the creed. The first appeals to credal belief are found in St. Paul's epistles : they reappear continually in the apostolic and subapostolic Fathers. After the explicit formulation of the creed at Nicaea that creed forms the principle of differentiation between the Christian and the unbeliever. We are almost amazed sometimes at the minuteness with which the words of the creed were analysed and defended. The sacredness of its text was maintained with a degree of veneration equalled only by that which the upholders of verbal inspiration have paid to the actual words of the Bible. Indeed the early Greek and Latin Church might be called 'the Church of the infallible creed' : and western Protestantism, until last generation, 'the Church of the infallible Bible.' Yet the creed was not the object of a mere unreasoning acceptance : it would be truer to say that it was regarded as an unsurpassable statement of the faith in intellectual terms, devised under the direct guidance of the Holy Spirit. To such a writer as Athanasius the Nicene creed was a conscious endeavour to reconcile the characteristic principles of eastern and western thought with the truth as revealed in the incarnation; and as such he uses it both as a constructive defence against philosophic attack from without, and as the foundation of positive belief within the Church.

In the providence of God it has come about that a large proportion of missionary work to-day is in the hands of those Christian bodies which base Christianity chiefly upon personal experience, and pay far less attention either to the intellectual formulation of faith, or to the outward form of organization in which it has been clothed in the course of history. This attitude of mind is well illustrated by several articles in the number of this Review for October 1918, all 
bearing upon the relation between the future indigenous Church in the East and the present indigenous Church in the West. To one who belongs to a branch of the Church which attaches great importance to the traditional form, verbal and ecclesiastical, of Christianity, it seems that these writers are not aware of the great storehouse of wisdom which lies ready to their hand in the literature of the early Church, nor of the practical bearing which much of that literature has upon the missionary problems of to-day. Patristic literature sets before us in its gradual development the policy which ultimately led to the establishment of Christianity as the religion of Europe, and at the same time supplies a stupendous wealth of arguments wherewith to justify Christianity in the eyes of an oriental society, already deeply influenced by western modes of thought. Surely it needs only to be once stated in order to be accepted, that for enlightenment as to the principles of missions to-day we must turn, not to the Reformation theology, which was directed solely to the revitalizing of a decadent Christianity in western nations, already over-familiar with the outward forms of that religion, but to the subapostolic and patristic theology, constructed by men who passed no small part of their time in presenting the Christian faith to representatives of the East, and in combating beliefs resembling in tone and drift just those held by Buddhists or Hindus to-day. The veneer of Graeco-Roman civilization which overlay the primitive thoughts and impulses of the Oriental of the first century is very similar to that veneer of European science which we see in the educated Oriental of the twentieth century. Hence the text-books of eastern missions to-day should be rather the works of Origen and Athanasius and Cyril than those of Luther or Wesley or modern western Protestantism. The intense emphasis on individual experience which has given Methodism its success in the West is surely out of place among the socially-minded millions of the East. The man of the West glories in standing alone : to the Oriental the attitude of his family, his caste, 
his nation, is so inextricably interwoven with all his thoughts that to stand alone is difficult to the point of impossibility, unless he has first by personal contact and education become imbued with something of the individualism of the West and been to no small extent denationalized in the process.

Again, the East is a land where the deepest respect is paid to ancient institutions, ancient forms, ancient ceremonies of religion. That respect is more fundamental than the recently acquired enthusiasm for copying the cruder ideals of industrial and political efficiency, now manifested in Japan, China and India. Therefore one must be justified in expecting that the thought of the unbroken continuity of the Church's life is one which will make a powerful appeal to the eastern mind. Yet that thought of historical continuity seems to be almost wholly absent from the minds of many writers upon the problem of the indigenous Church in the East. They may indeed appeal to the continuity of religious experience : to the fact that Christians of all ages have found in Jesus Christ their personal Saviour: but that statement is too subjective, too individual to satisfy that craving for historical continuity natural to such a country as India, whose religions are of such vast antiquity.

Yet again, the sacramental conception in its broadest outline, i.e. the thought of so close an interrelation of the spiritual and the material as makes it possible for us to regard material things as vehicles of spiritual gifts, is in fullest agreement with the oriental mystical attitude to matter.

Once more, the position of the ordained ministry as divinely accredited messengers is one which it is easy for the East to grasp and to accept, for though India could listen to the Buddha, who was a prophet but no priest, yet the mass of Indians are guided in their daily religion by those who, however unworthily, hold in their eyes the position of divinely appointed guides and pastors. The grosser excrescences of belief in priestly mediation were excised for ever from Anglo-Saxon Christianity at the 
Reformation : but the inner principle, as revealed in St. Paul and St. John, remains and will appeal to the natural bent of the Oriental.

To sum up, then, the line of argument of this paper : The first assumption is that the present century finds very numerous parallels in the general situation of Christianity in the early centuries of the Church ; for then, and never since, the Church stood actually midway between East and West, in intimate contact with both. Therefore it is but reasonable to look to the writers of those centuries for guidance in our attempts to solve the pressing problems of to-day. The principles which they expound are very different from those accepted by many writers on modern missions, but appear to the present writer, looking at the problem in no controversial spirit, but with an earnest desire that the eastern Church of the future should grow up along lines truly in accordance with the will of God, to be at once more applicable to oriental conditions and more securely based in history than the principles of individualism, which so largely influence missionary policy to-day.

E. B. A. Somerset 